\title{
Elements in water, suspended particulate matter and sediments of the Sava River
}

\author{
Janja Vidmar $^{1,2} \cdot$ Tea Zuliani $^{1} \cdot$ Petra Novak $^{1,2} \cdot$ Ana Drinčić $^{1,2}$. \\ Janez Ščančar ${ }^{1,2} \cdot$ Radmila Milačič $^{1,2}$
}

Received: 29 March 2016 / Accepted: 13 July 2016 / Published online: 25 July 2016

(C) The Author(s) 2016. This article is published with open access at Springerlink.com

\begin{abstract}
Purpose River ecosystems are under pressure from several different stressors. Among these, inorganic pollutants contribute to multiple stressor situations and the overall degradation of the ecological status of the aquatic environments. The main sources of pollution include different industrial activities, untreated effluents from municipal waste waters and intensive agriculture. In the present study, water, suspended particulate matter (SPM) and sediments of the Sava River were studied in order to assess the pollution status of this river system.

Materials and methods Sampling was performed during the first sampling campaign of the EU 7th FW funded GLOBAQUA project in September 2014, at 18 selected sampling sites along the Sava River. In 2014, floods predominated from spring to fall. Water samples were collected to determine the total element concentrations, the dissolved $(0.45 \mu \mathrm{m})$ fraction and element concentrations in SPM. In order to assure comparative results with other river basins, the fraction below $63 \mu \mathrm{m}$ was analysed in sediments. The extent of pollution was estimated by determination of the total element concentrations and by the identification of the most hazardous highly mobile element fractions (extraction $0.11 \mathrm{~mol} \mathrm{~L}^{-1}$ acetic acid) and
\end{abstract}

Responsible editor: Nives Ogrinc

Electronic supplementary material The online version of this article (doi:10.1007/s11368-016-1512-4) contains supplementary material, which is available to authorized users.

Radmila Milačič

Radmila.milacic@ijs.si

1 Department of Environmental Sciences, Jožef Stefan Institute, Jamova 39, 1000 Ljubljana, Slovenia

2 Jožef Stefan International Postgraduate School, Jamova 39, 1000 Ljubljana, Slovenia anthropogenic inputs of elements to sediments (normalization to aluminium (Al) concentration). Concentrations of selected elements were determined by inductively coupled plasma mass spectrometry (ICP-MS).

Results and discussion Since during sampling campaign the water level was extremely high, water samples contained high amounts of SPM (in general between 80 and $100 \mathrm{mg} \mathrm{L}^{-1}$ ). The data of chemical analysis revealed that concentrations of elements in water, SPM and sediments in general increase along the Sava River from its origin to the confluence with the Danube River. Elevated concentrations of chromium (Cr) and nickel (Ni) in SPM and sediments were observed at industrially exposed sites. Concentrations of $\mathrm{Cr}$ and $\mathrm{Ni}$ in sediments were up to 320 and $250 \mathrm{mg} \mathrm{kg}^{-1}$, respectively. Nevertheless, these elements were present in sparingly soluble forms and hence did not represent an environmental threat. Phosphorus (P) was found in elevated concentrations (up to $1500 \mathrm{mg} \mathrm{kg}^{-1}$ ) at regions with intensive agricultural activities and cities with dense population.

Conclusions With respect to element concentrations, the pollution of the Sava River is similar to other moderately polluted European rivers. The data from the present study are beneficial for the water management authorities and can contribute to sustainable utilization, management and protection of the Sava River water resources.

Keywords Elements · Environmental status - Sediments · Suspended particulate matter · The Sava River · Water

\section{Introduction}

The quality of groundwater within the Sava River basin, which is an important source of drinking water for the population of the riparian countries, depends strongly on the quality 
of the Sava River water (International Sava River Basin Commission 2013). Sediments that represent a source of nutrients for microorganisms have a strong impact on the ecosystem functioning. On the other hand, they may accumulate different contaminants, which can be remobilised into the aqueous phase, causing hazardous effects on the aquatic organisms (Kwok et al. 2014). So, water and sediment quality is of great importance for sustaining the health of benthic life. The sediment quality is essential in the development of management plans when dredging of sediments is necessary for restoring waterways and when accumulated sediments from hydroelectric power plant accumulation basins need to be removed (International Sava River Basin Commission 2002). Moreover, chemical analyses of sediments are frequently applied as they reveal spatial and temporal variation in elemental concentrations (Loring and Rantala 1992; Grosbois et al. 2006; Meybeck et al. 2007; Mohiuddin et al. 2012). Among different pollutants, elements present in elevated concentrations in water and sediments may considerably contribute to multiple stressor conditions of the aquatic environment.

For water analysis, standard methods for the examination of surface waters are recommended (Gottler 2012; ISO 15586 2003; ISO 5667-3 2012). These methods are also regulated in the Water Framework Directive (WFD) 2000/60/EC (Official Journal of the European Communities 2000) and its daughter Directive 2009/90/EC (Official Journal of the European Union 2009), and in environmental objectives for surface waters (European Communities Environmental Objectives 2009). In the EU directives (Official Journal of the European Union 2009; European Communities Environmental Objectives 2009) and ISO 6777-3 standard (ISO 5667-3 2012), filtration of whole water sample through a $0.45-\mu \mathrm{m}$ filter is required for the determination of the dissolved metal fraction. In standard methods for the examination of water and wastewater (Gottler 2012), in surface water analyses, the dissolved metal fraction (filtering through $0.45 \mu \mathrm{m}$ filter) and total metal fraction, which are defined operationally (nitric acid digestion, nitric acid-sulphuric acid digestion, nitric acid-perchloric acid digestion, nitric acid-perchloric acidhydrofluoric acid digestion and microwave-assisted digestion), are recommended for regular analysis.

In sediment analysis, it is not possible to estimate the extent of pollution only by the determination of the total element concentration. Namely, the bioavailability and toxicity of element depend primarily on chemical forms in which it is present in a given environmental compartment. By applying fractionation procedures, valuable information on the partitioning of elements between easily and sparingly soluble fractions of sediments can be obtained. Knowing the concentration of a particular element in the easily soluble fraction enables evaluation of its potential harmful effects to the aquatic biota. In sediment analyses, Tessier's fractionation procedure (Tessier et al. 1979) or BCR scheme proposed by the Community
Bureau of Reference (Quevauviller et al. 1997) was commonly applied. The leaching protocol of the first step of these sequential extraction procedures is also used to investigate the easily soluble element fraction, applying aqueous solutions of $1 \mathrm{~mol} \mathrm{~L}^{-1}$ ammonium chloride (Tessier et al. 1979) or $0.11 \mathrm{~mol} \mathrm{~L}^{-1}$ acetic acid (Quevauviller et al. 1997) as extracting agents. Data on mobility and potential bioavailability of elements in sediments represent a good basis for the estimation of the environmental burden (Svete et al. 2001; Vasile et al. 2010; Milačič et al. 2010; Dundar et al. 2012) and are useful also in the management of dredged sediments (Šömen Joksič et al. 2005; Alvarez-Guerra et al. 2007; Zuliani et al. 2016). For estimation of the natural and anthropogenic input of elements in sediments, normalization procedures, based on correlations between the concentration of trace elements and the element that is naturally present in the environment investigated, are applied. For this purpose, aluminium (Al) as a major constituent of aluminosilicates and iron $(\mathrm{Fe})$ as a clay mineral indicator element have been the most frequently used (Loring and Rantala 1992; Svete et al. 2001; Kotnik et al. 2003; Milačič et al. 2010).

Elements like cadmium $(\mathrm{Cd})$, lead $(\mathrm{Pb})$, copper $(\mathrm{Cu})$, zinc $(\mathrm{Zn})$, chromium $(\mathrm{Cr})$, nickel $(\mathrm{Ni})$ and arsenic $(\mathrm{As})$ are frequently present in sediments due to industrial (Giusti and Taylor 2007; Karadede-Akin and Ünlü 2007; Sakan et al. 2010), municipal (Grosbois et al. 2006) and mining activities (Svete et al. 2001; Bird et al. 2010), whereas phosphorous (P) is accumulated in sediments mainly as a consequence of the use of fertilisers at riparian agricultural areas (House and Denison 2002) or is released from municipal sewage treatment plants (Howell 2010).

For evaluation of the environmental status of sediments, various sediment quality guidelines have been proposed, based mainly on the biological effect approaches (CCME 2001; McCready et al. 2006; Long et al. 2006). MacDonald et al. (2000) developed and evaluated consensus-based sediment quality guidelines for freshwater ecosystems, including a threshold effect concentration (TEC) below which harmful effects are unlikely to be observed, and a probable effect concentration (PEC) above which harmful effects are likely to be observed. As a part of common implementation strategy for the WFD, the European Commission has issued technical guidance for the derivation of sediment quality guidelines (European Communities Technical Report 2010-041 2010). To optimise sediment management alternatives and to improve quality assessment criteria, sediment guidelines are still being developed (Bakke et al. 2010; Kwok et al. 2014; Merrington and Sprang 2014).

In support of reducing the pressure of multiple stressors on aquatic ecosystems and for optimal management of the water resources, the European Union granted the 7th FW project GLOBAQUA (Navarro-Ortega et al. 2015) in which the Sava River is one of the river basins investigated. Elements 
are among pollutants that contribute to the multiple stressor conditions. Despite the fact that national environmental agencies regularly monitor the water quality of the Sava River, data on the environmental status of the river basin are still missing. Therefore, the aim of the present work was to determine the concentrations of elements in water, suspended particulate matter (SPM) and sediments of the Sava River, collected during a sampling campaign in September 2014.

\section{Materials and methods}

\subsection{Sampling}

The Sava River sampling campaign was carried out from September 1 to 10,2014 , on nine water units along the river at automatic gauging stations, providing the data for water level, temperature and discharge. The Lagrangian approach to sample of the same water mass upstream at the input (1) and downstream at the output (2) boundaries of the selected river water unit was applied (Writer et al. 2011). This enabled to relate transformations of dissolved and suspended contaminant compounds with the travel time. The water travel time was determined empirically by a velocity metre. The water units were 10 to $30 \mathrm{~km}$ long. Sampling sites, sample codes and sampling site characteristics are provided in Fig. 1 and online measurement parameters (dissolved oxygen, electrical conductivity and $\mathrm{pH}$ ) in Table S1 (Electronic Supplementary Material). The normal average discharge for Litija (Slovenia) is around $50 \mathrm{~m}^{3} \mathrm{~s}^{-1}$ and for Sremska Mitrovica (Serbia) around $500 \mathrm{~m}^{3} \mathrm{~s}^{-1}$. During the sampling campaign, flood conditions prevailed, which was evident from elevated water discharges: the water discharge in Litija (Slovenia) was $300 \mathrm{~m}^{3} \mathrm{~s}^{-1}$ and in Sremska Mitrovica (Serbia) $3300 \mathrm{~m}^{3} \mathrm{~s}^{-1}$. Sampling of water was carried under requirements of the WFD (Official Journal of the European Communities 2000; Official Journal of the European Union 2009; European Communities Environmental Objectives 2009) and ISO 5667-3 standard (2012), while that of SPM and sediments is described in the sediment quality guidelines (European Communities Technical Report 2010-041 2010). Since in Jasenovac, Slavonski Brod and Županja (Croatia) the area was flooded, it was not possible to take the sediment samples.

From each sampling site, water was collected into 10-L plastic buckets. An aliquot of $1 \mathrm{~L}$ was then taken for SPM analysis and $1 \mathrm{~L}$ for the determination of elements in whole water samples and dissolved element fraction. Approximately $2 \mathrm{~kg}$ of sediments were collected in 2-L plastic bottles.

\subsection{Analytical procedures}

Water samples To determine the soluble metal concentrations, water samples were filtered before analysis (Official
Journal of the European Communities 2000; European Communities Environmental Objectives 2009; Gottler 2012). For the determination of the total metal concentrations, $10 \mathrm{~mL}$ of whole water samples was transferred to Teflon vessels and $4 \mathrm{~mL}$ of supra pure $\mathrm{HNO}_{3}, 2 \mathrm{~mL}$ of supra pure $\mathrm{HF}$ and $1 \mathrm{~mL}$ of supra pure $\mathrm{HCl}$ added. The Teflon vessels were covered and subjected to microwave-assisted digestion by ramping the temperature to $200{ }^{\circ} \mathrm{C}$ in $30 \mathrm{~min}$, holding the same temperature for the next $60 \mathrm{~min}$ and cooling the contents in the following $30 \mathrm{~min}$. Supra pure $\mathrm{H}_{3} \mathrm{BO}_{3}(12.5 \mathrm{~mL}, 4 \%$ aqueous solution) was then added for complexation of fluorides and the contents digested again by ramping the temperature to $200{ }^{\circ} \mathrm{C}$ in $15 \mathrm{~min}$, holding the same temperature for the next $30 \mathrm{~min}$ and cooling the contents in the following 30 min (Zuliani et al. 2016). Acidification of the sample as recommended in the standard methods for the examination of water and wastewater (Gottler 2012) was also applied to determine the total metal content. For this purpose, $1 \mathrm{~mL}$ of supra pure $\mathrm{HNO}_{3}$ was added to $1 \mathrm{~L}$ of the whole water sample. Concentrations of elements in water samples were determined by ICP-MS (Novotnik et al. 2015).

Sediment and SPM samples For the determination of the total element content in sediments, approximately $0.25 \mathrm{~g}$ of samples was added to Teflon vessels and microwave-assisted digestion as described above performed. To determine the total element content in SPM, samples were first filtered (Gottler 2012), the filter transferred to Teflon vessels and microwave digestion of the mineral phase as described above applied. Metal concentrations in sediments and SPM were determined by ICP-MS.

Quality control The accuracy of the analytical procedures used in the present study was checked by the analysis of appropriate certified reference materials. As is evident from Table S2 (Electronic Supplementary Material), good agreement of data (better than $\pm 5 \%$ ) was obtained between the determined concentrations of elements and the reported certified values. The expanded uncertainty of analytical procedures applied was better than $\pm 3 \%(\mathrm{k}=2)$.

\section{Determination of the easily soluble metal concentrations in} sediments and normalization to Al Acetic acid $\left(0.11 \mathrm{~mol} \mathrm{~L}^{-1}\right)$ was used to extract the easily soluble element fraction from sediment (Milačič et al. 2010) and the element content determined by ICP-MS. In order to account for geochemical variations along the Sava River, a normalization of total sediment concentrations by a conservative element $\mathrm{Al}$ was applied (Milačič et al. 2010). Significant deviations from the linear relationship were used to differentiate between natural vs. anthropogenic inputs. 


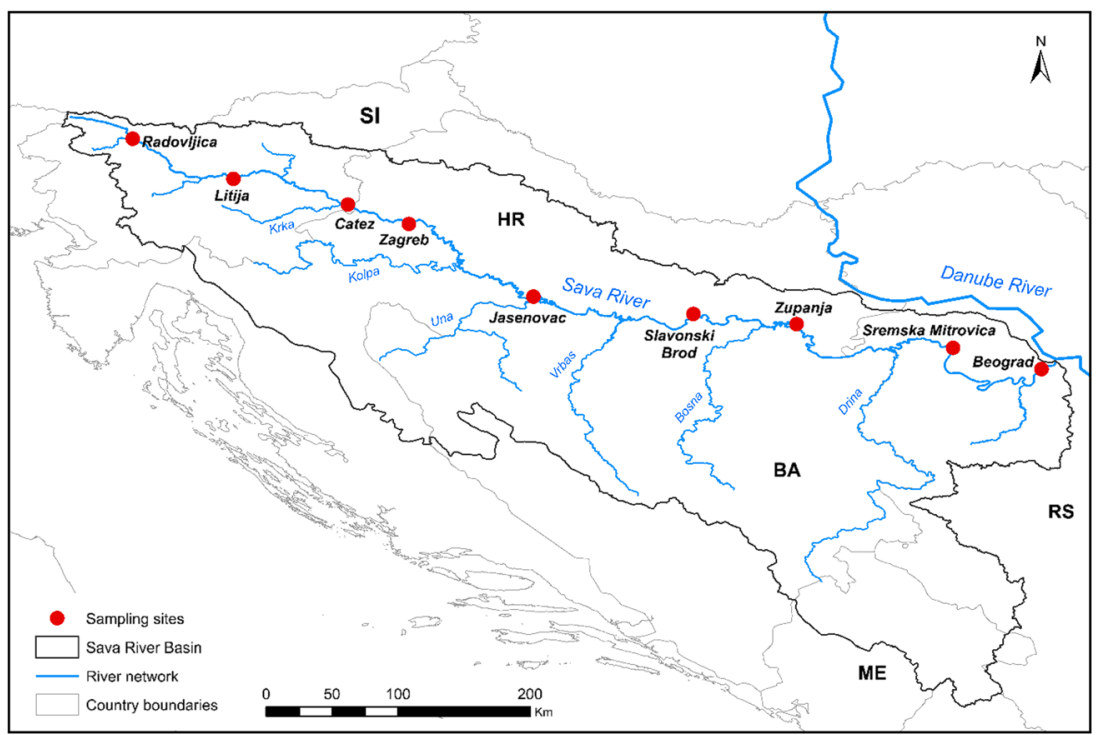

Fig. 1 The Sava River sampling locations, sampling codes and main sampling site characteristics (sampling campaign September 2014). Radovljica (SI) RAD1 = 46.340840, 14.165080; RAD2 $=46.292979$, 14.260754 (small city at the confluence of the Sava Dolinka and the Sava Bohinjka, both headwaters of the Sava River). Litija (SI) LIT1 = 46.084561, 15.582632; LIT2 = 46.066191, 14.850857 (land use, abandoned mining area). Čatež (SI) CAT1 $=45.896355$, 15.627037; CAT2 $=45.860357,15.692068$ (land use). Zagreb (HR) ZAG1 $=45.783014,16.003184 ;$ ZAG2 $=45.770897,16.069357$ (big city, urban pollution). Jasenovac (HR) JAS1 $=45.263968,16.894432$;

\section{Results and discussion}

\subsection{Analysis of element concentrations in whole water samples}

For the analysis of element concentrations in the whole water samples, microwave-assisted digestion and acidification of samples with $\mathrm{HNO}_{3}$, as described in Sect. 2.2, were applied and concentrations of elements determined with ICP-MS. These results are presented in Table 1 and Table S3 (Electronic Supplementary Material) and the mass of SPM in the water samples in Fig. 2. As evident, great differences in element concentrations are observed between the microwave-assisted digestion of water samples and acidification procedure, since acidification just desorbed the elements from particles, while elements that are associated with the matrix constituents could not be decomposed in this way. Due to this reason, microwave-assisted digestion gave significantly higher results than did acidification with $\mathrm{HNO}_{3}$, in particular in elements, which are major constituents of the mineral phase of the SPM (e.g. Fe, Al, Ti) (Table 1). This is related to high mass of SPM in water samples, ranging from around 50 up to $140 \mathrm{mg} \mathrm{L}^{-1}$. Similar behaviour, but in lesser extent, was observed also for $\mathrm{Cr}, \mathrm{Ni}, \mathrm{Cd}, \mathrm{Zn}, \mathrm{Cu}$ and $\mathrm{As}$ (Table 1), as well as for Se, Sb, Co and Mn (Table S3, Electronic Supplementary Material). These data revealed that
JAS2 = 45.250861, 16.951914 (navigation, land use). Slavonski Brod (HR) SLB1 = 45.152703, 18, 013,906; SLB2 = 45.126224, 18.084751 (navigation, oil refinery, land use). Županja (HR) ZUP1 $=45.074805$, 18.687667; ZUP2 = 5.014880, 18.740313 (navigation, oil refinery, metallic and mining industry, land use). Sremska Mitrovica (RS) SRM1 $=44.973390,19.596213 ;$ SRM2 $=44.913582,19.752412$ (navigation, oil refinery, heavy industry, land use). Beograd (RS) $\mathrm{BEO} 1=44.769133,20.355572 ; \mathrm{BEO} 2=44.806317,20.443683$ (navigation, big city, urban pollution)

in samples with high SPM content, microwave-assisted digestion of water samples should be applied for the determination of the element concentrations in the whole water samples.

\subsection{Selected elements in water samples, suspended particulate matter and sediments}

Concentrations of 18 selected elements, $\mathrm{Cr}, \mathrm{Ni}, \mathrm{Cd}, \mathrm{Zn}, \mathrm{P}, \mathrm{Pb}$, $\mathrm{As}, \mathrm{Cu}, \mathrm{Sb}, \mathrm{V}, \mathrm{Mo}, \mathrm{Co}, \mathrm{Se}, \mathrm{Ba}, \mathrm{Mn}, \mathrm{Ti}, \mathrm{Fe}$ and $\mathrm{Al}$, were determined in the water (whole water samples (microwaveassisted digestion) and dissolved element fraction $(<0.45 \mu \mathrm{m}))$, SPM and sediment samples (total element concentration after microwave-assisted digestion and the easily soluble element fraction (extraction in $0.11 \mathrm{~mol} \mathrm{~L}^{-1}$ acetic acid)). Normalization of the total element concentrations in sediments vs. total Al concentration was also applied to assess the anthropogenic inputs of elements in sediments. The results of these investigations are for $\mathrm{Cr}, \mathrm{Ni}, \mathrm{Cd}$ and $\mathrm{Zn}$ presented in Fig. 3. Data for Al that was used for normalization are presented in Fig. S1 (Electronic Supplementary Material) and for other elements in Fig. S2 (Electronic Supplementary Material).

The data indicate that concentrations of elements in water, SPM and sediments in general increase along the Sava River towards its confluence with the Danube River (Belgrade). Total element concentrations in the whole water samples are 


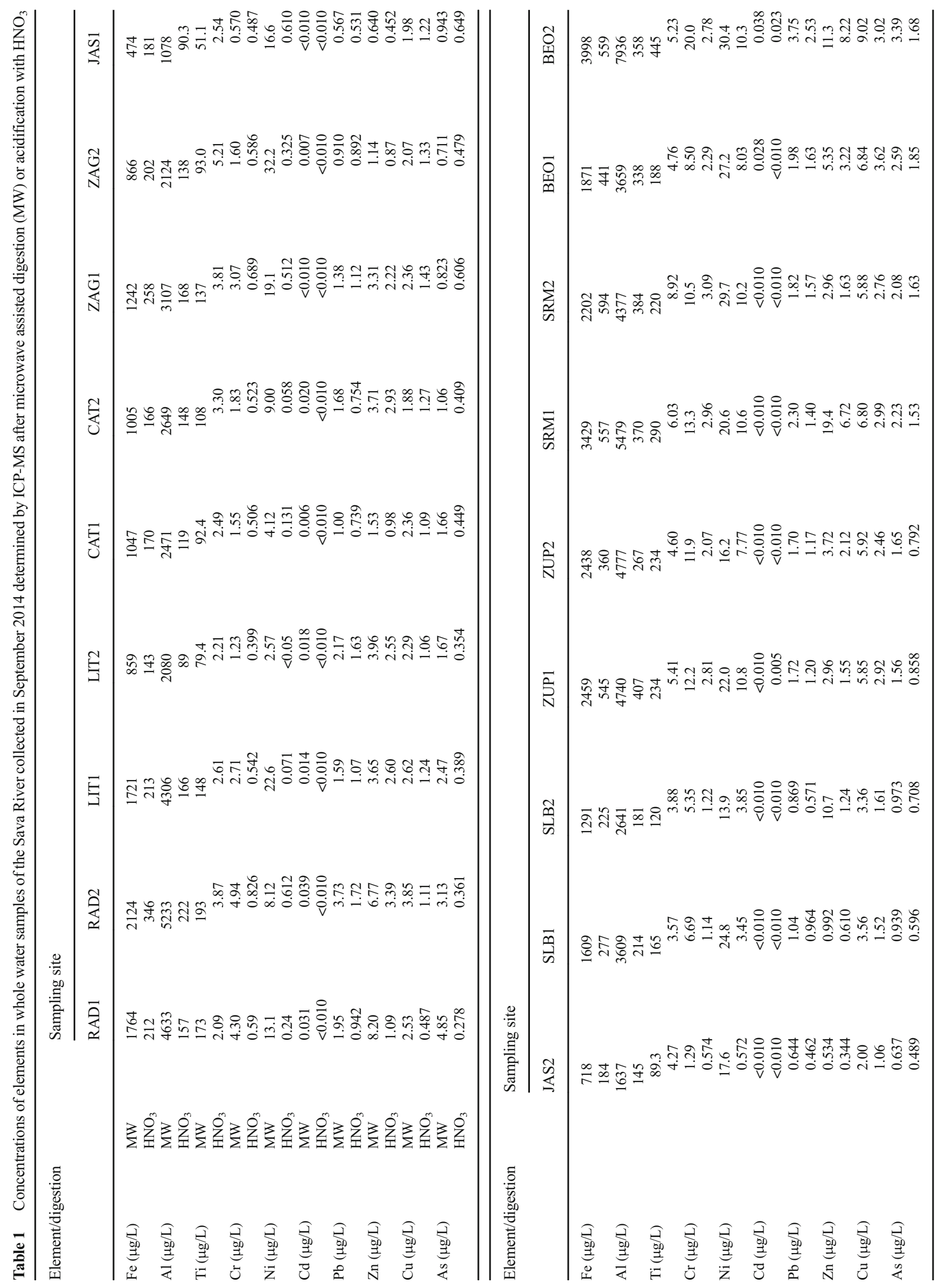


Fig. 2 Mass of SPM in water samples of the Sava River collected in September 2014

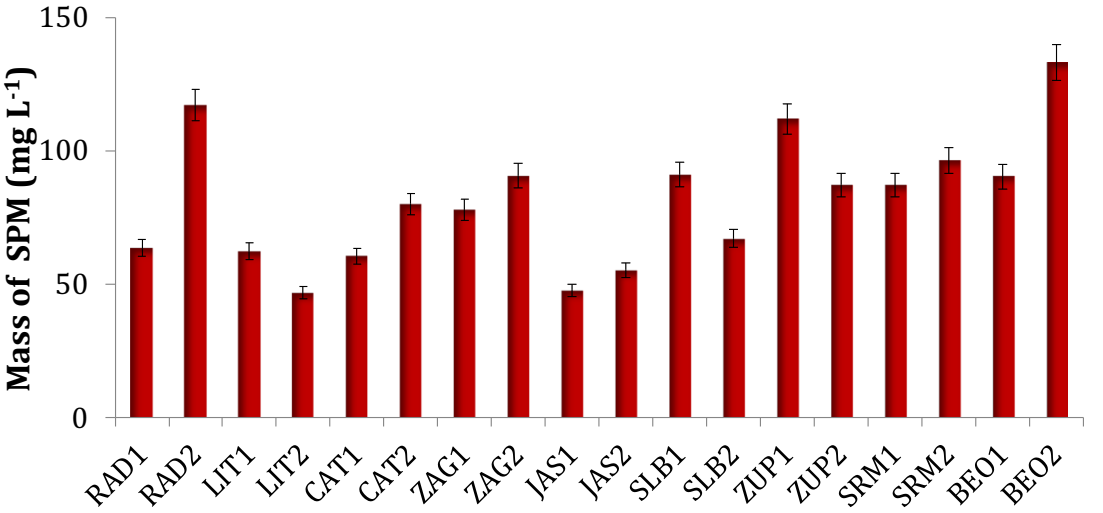

Sampling site significantly higher from the dissolved element fraction (samples filtered through a $0.45-\mu \mathrm{m}$ filter), which is related to flooding conditions during the sampling campaign and, consequently, to high SPM content in the water samples. From comparison of concentrations of elements in the whole water samples at the input (1) and output (2) boundaries of the selected river water unit (Fig. 3 and Fig. S2 in the Electronic Supplementary Material), there is no evidence on general attenuation of total element concentrations in the whole water samples. It can be therefore concluded that the Lagrangian approach is not applicable to big rivers, such as Sava. Regarding the dissolved element fraction, concentrations of $\mathrm{Cd}, \mathrm{Pb}, \mathrm{Ni}, \mathrm{Cu}, \mathrm{Cr}$, As and $\mathrm{Zn}$ did not exceed the limit values regulated by the WFD and environmental objectives for surface waters (Official Journal of the European Communities 2000; European Communities Environmental Objectives 2009). Concentrations of soluble Fe, Mn, $\mathrm{Zn}$ and Co determined in the present study were similar, dissolved $\mathrm{Cd}$ concentrations were lower, while concentrations of $\mathrm{Pb}, \mathrm{Ni}$ and $\mathrm{Cu}$ were found slightly higher (mainly at industrial sites) in comparison to those previously reported for the Sava River by Dragun et al. (2009, 2011).

From data of Fig. 3 and Fig. S2 (Electronic Supplementary Material), it is further evident that concentrations of elements in SPM along the Sava River were lower than total element concentrations in sediments. The grain size of SPM is typically around $30 \mu \mathrm{m}$ and is usually smaller than in sediments (Bouche et al. 2011). The main constituents of SPM are phyllosilicate minerals and carbonates, which are relatively light and are preferentially transported at the surface of the water column (Bouche et al. 2011). In comparison to clay fraction, which is an important constituent of bed sediments and rich in trace elements, phyllosilicate and carbonate mineral phases contain lower concentrations of trace elements. The other possible reason that concentrations of elements determined in SPM were lower than in sediments is that during flooding events, particles from soils, which may be less contaminated than sediments, were discharged in the river.
The data in Fig. 3 and Fig. S2 (Electronic Supplementary Material) also indicate that the easily soluble element fraction represented in general below $5 \%$ of the total element concentrations. Higher percentages of the soluble element fractions (20-50\%) were observed for $\mathrm{Ba}, \mathrm{Cd}, \mathrm{Mn}$ and $\mathrm{Co}$.

Considering the total element concentrations in sediments, the Sava River is moderately polluted with $\mathrm{Cr}$ and $\mathrm{Ni}$. At all sampling sites, $\mathrm{Cr}$ concentrations in sediments were higher than the TEC value (43.4 $\mathrm{mg} \mathrm{kg}^{-1}$ ) (MacDonald et al. 2000). $\mathrm{Cr}$ concentrations highly exceeded also the PEC value of $111 \mathrm{mg} \mathrm{kg}^{-1}$ (MacDonald et al. 2000) at sampling sites RAD1, SRM1 and SRM2 and BEO1 and BEO2, while at sampling sites RAD2, LIT2 and CAT2, Cr concentrations were slightly higher than the PEC value. Similarly as for $\mathrm{Cr}$, Ni concentrations exceeded TEC values $\left(22.7 \mathrm{mg} \mathrm{kg}^{-1}\right)$ at all sampling sites. The PEC value (48.6 mg kg-1) was slightly exceeded at RAD1, while at sampling sites SRM1 and SRM2 and BEO1 and BEO2, total Ni concentrations in sediments highly exceeded the PEC value. Data from normalization to $\mathrm{Al}$ indicate on anthropogenic inputs of $\mathrm{Cr}$ at sampling sites RAD1, SRM1 and SRM2 and BEO1. For Ni, anthropogenic inputs are evident at sampling sites SRM1 and SRM2 and BEO1 and BEO2. The sampling site RAD1 is impacted by the Acroni metal works Jesenice upstream of the Radovljica city, whereas sediments in Sremska Mitrovica and Beograd (SRM1, SRM2 and BEO1, BEO2) are influenced by the heavy metal and chemical industry from the area. $\mathrm{Cr}$ and Ni concentrations at sampling sites influenced by the industrial activities ranged from 180 up to $320 \mathrm{mg} \mathrm{kg}^{-1}$ and from 100 to $250 \mathrm{mg} \mathrm{kg}^{-1}$, respectively. These $\mathrm{Cr}$ and $\mathrm{Ni}$ concentrations are comparable to those determined in sediments of the Sava River in 2005-2006 (Milačič et al. 2010). Vignati et al. (2003) reported similar concentrations for $\mathrm{Cr}$ and $\mathrm{Ni}$ found in sediments of the Po River, Italy, which were determined during normal and high flow conditions (120 to 230 and 100 to $240 \mathrm{mg} \mathrm{kg}^{-1}$, respectively). Nevertheless, $\mathrm{Cr}$ and Ni concentrations in sediments of the Sava River from industrial areas are higher than most of the data reported for the Danube River 

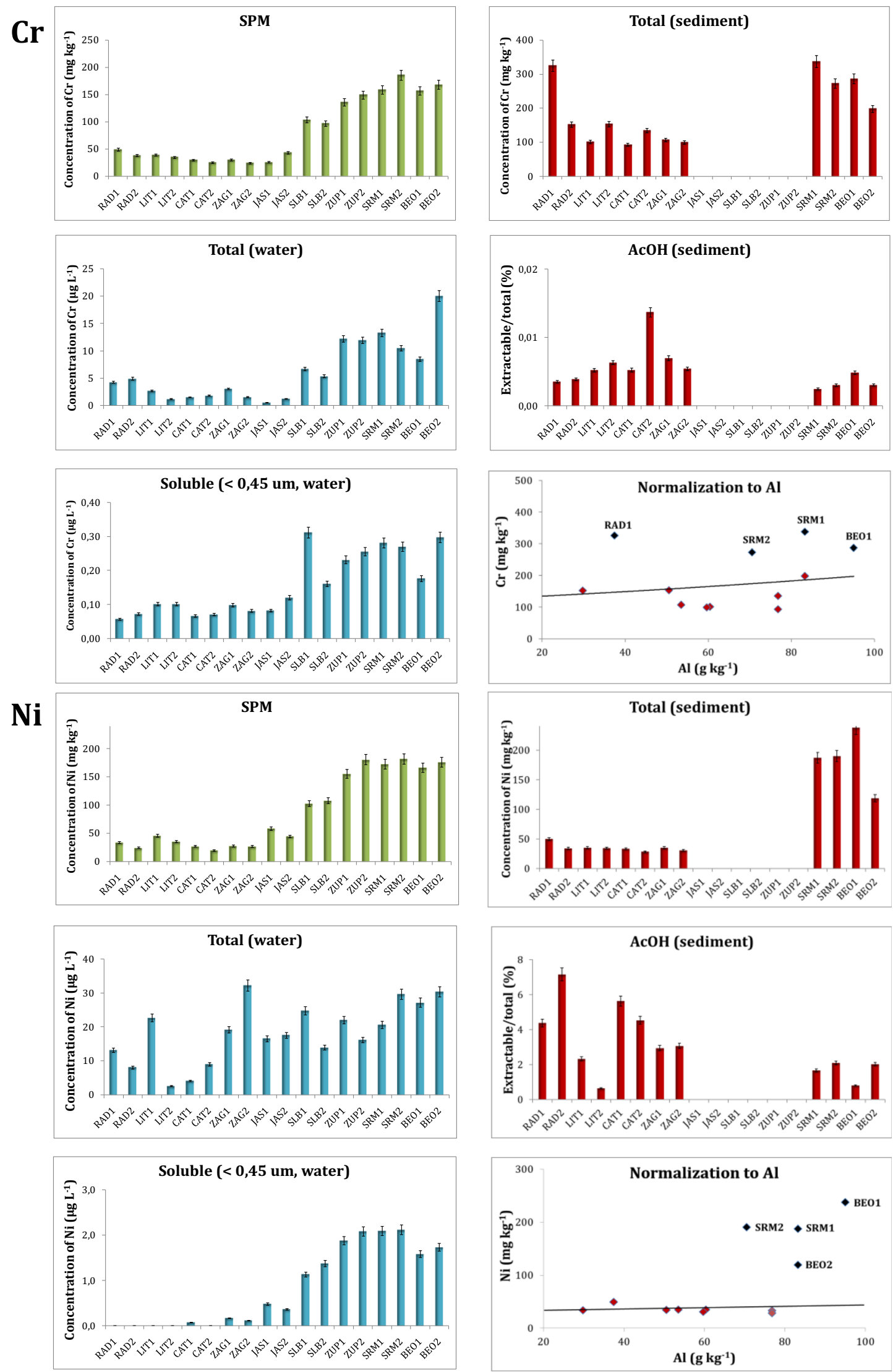

Fig. 3 Total element concentrations in water samples, suspended particulate matter and sediments. Data for the easily soluble element fraction in sediments and normalization to $\mathrm{Al}$ are also given 
Cd
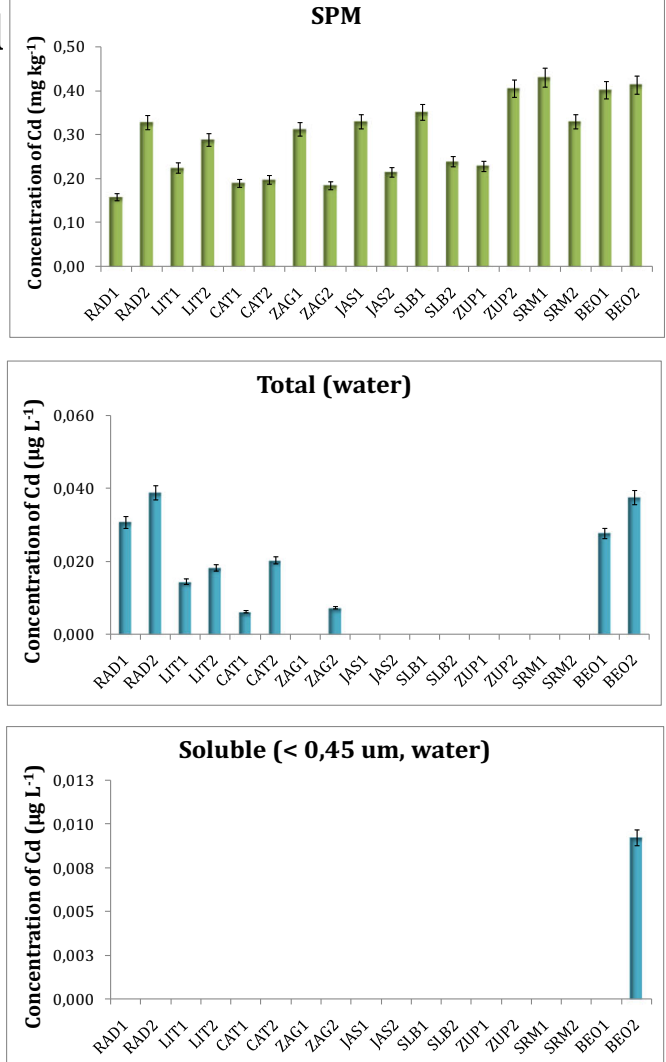

Zn
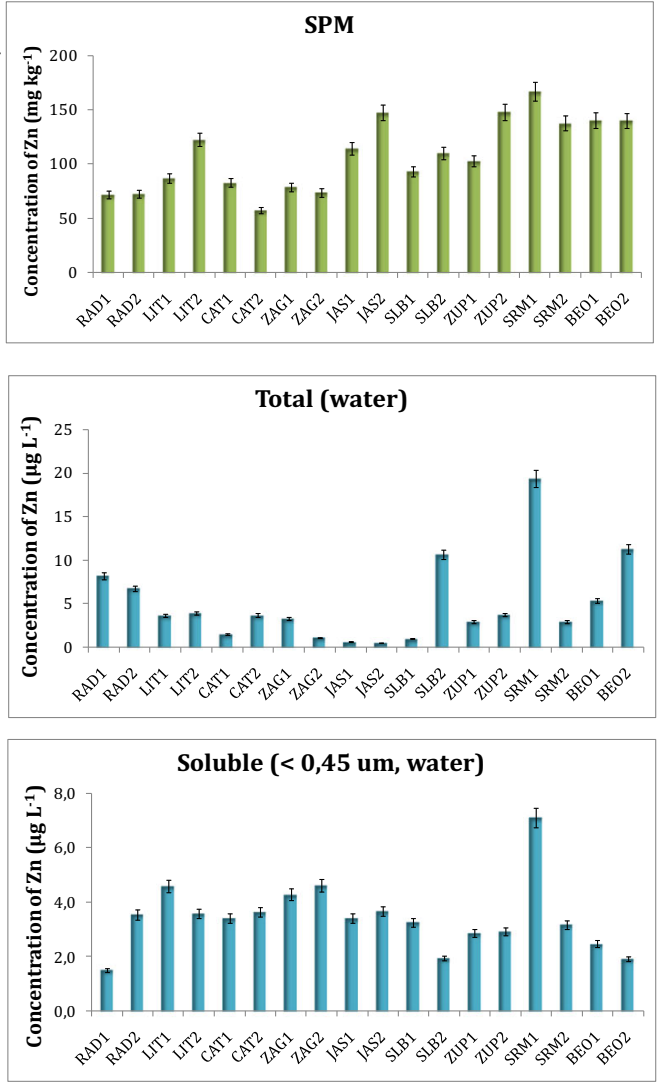

Total (sediment)

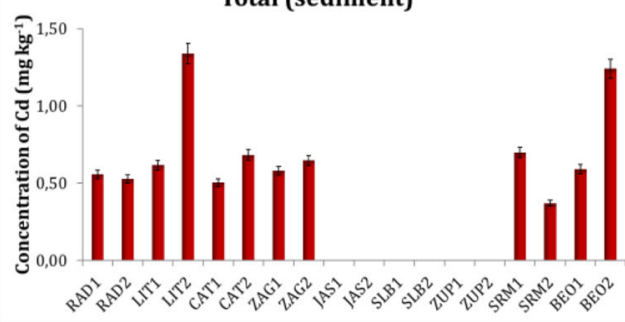

AcOH (sediment)
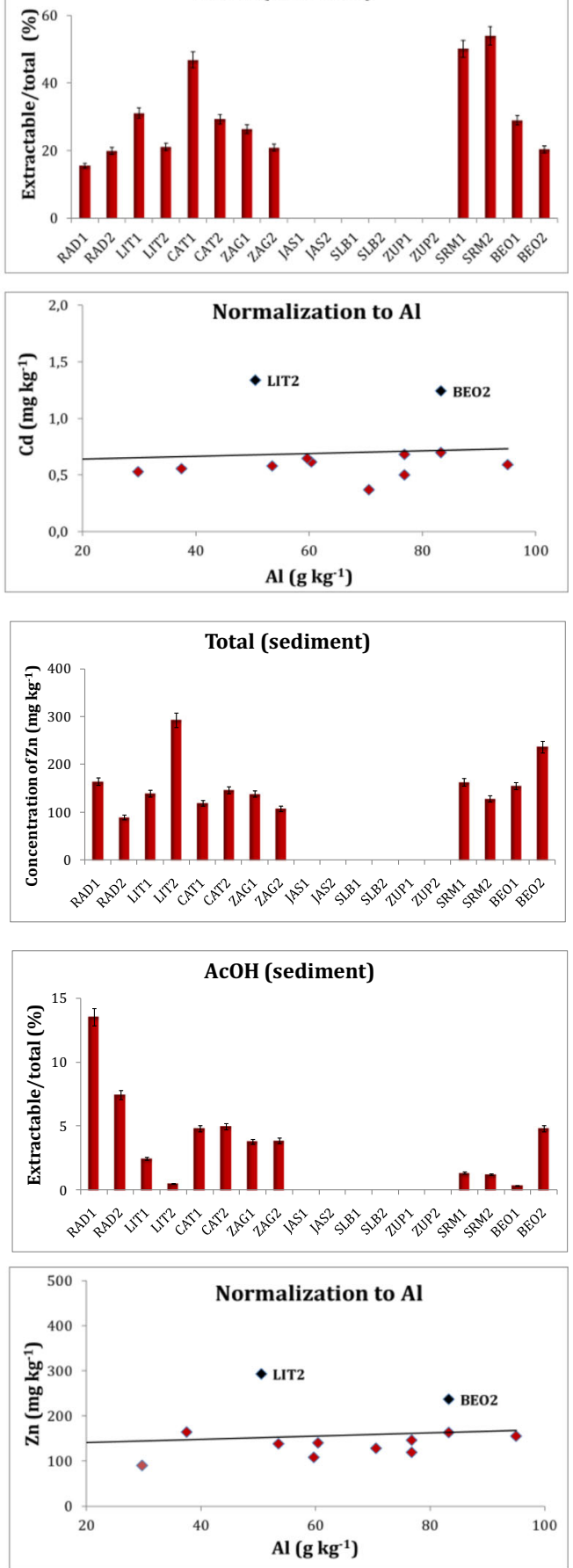

Fig. 3 (continued.) 
(around 150 and $100 \mathrm{mg} \mathrm{kg}^{-1}$, respectively) (ICPDR 2008; Sakan et al. 2010; Vignati et al. 2013; Comero et al. 2014). Data from Fig. 3 further revealed extremely low $\mathrm{Cr}$ mobility and low mobility of Ni. Namely, below $0.015 \%$ of total Cr and not more than $8 \%$ of total Ni content were extracted with $0.11 \mathrm{~mol} \mathrm{~L}^{-1}$ acetic acid. As these two elements exist mainly in the sparingly soluble forms, it can be expected that $\mathrm{Cr}$ and $\mathrm{Ni}$ concentrations in sediments at industrially exposed sites do not represent an environmental burden.

$\mathrm{Cd}$ concentrations in sediments exceeded the TEC value $\left(0.99 \mathrm{mg} \mathrm{kg}^{-1}\right)$ only at LIT2 and BEO2, but were below the PEC value $\left(4.98 \mathrm{mg} \mathrm{kg}^{-1}\right)$, while $\mathrm{Zn}$ concentrations were in general higher than the TEC value $\left(121 \mathrm{mg} \mathrm{kg}^{-1}\right)$, but did not exceed the PEC value $\left(459 \mathrm{mg} \mathrm{kg}^{-1}\right)$. Anthropogenic inputs of $\mathrm{Cd}$ and $\mathrm{Zn}$ (normalization to Al data) at LIT2 arise from the former mining and metallurgy activities in Litija (Šajn and Gosar 2007) and in BEO2 as a consequence of an untreated sewage system in Belgrade (municipal wastewater treatment system in construction). Concentrations of $\mathrm{Cd}$ in sediments of the Sava River are comparable to sampling of sediments in 2005-2006 at the Sava River (Milačič et al. 2010) and to sediments of the Po River, Italy ( 0.4 to $1.4 \mathrm{mg} \mathrm{kg}^{-1}$ ) (Vignati et al. 2003). Meybeck et al. (2007) reported slightly higher $\mathrm{Cd}$ concentrations for the sediments of the Seine River, France (1 to $2 \mathrm{mg} \mathrm{kg}^{-1}$ ), and Kohušová et al. (2011) for the sediments of the Bílina River, Czech Republic (around $3 \mathrm{mg} \mathrm{kg}^{-1}$ ), while considerably higher $\mathrm{Cd}$ concentrations were found in sediments of the Danube River (around 2 to $3 \mathrm{mg} \mathrm{kg}^{-1}$ Cd) (ICPDR 2008). Nevertheless, recent reports indicate that $\mathrm{Cd}$ concentrations in Danube sediments tend to decrease (Sakan et al. 2010; Vignati et al. 2013; Comero et al. 2014). High proportions of the mobile fractions in sediments of the Sava River found for Cd (50\%) (Fig. 3) do not represent an environmental hazard, since the total concentrations of $\mathrm{Cd}$ were low. At sampling sites Litija and Beograd, where total $\mathrm{Cd}$ content in sediments was around $1.4 \mathrm{mg} \mathrm{kg}^{-1}$, the proportion in the easily soluble fraction was $20 \%$, so also at these sites the environmental burden from $\mathrm{Cd}$ was low. Concentrations of $\mathrm{Zn}$ in sediments of the Sava River are similar to those collected in 2005-2006 at the Sava River (Milačič et al. 2010) and are in most cases lower than that reported for the Danube River (ICPDR 2008; Sakan et al. 2010; Vignati et al. 2013; Comero et al. 2014) and River Po, Italy (Vignati et al. 2003) (200 to $500 \mathrm{mg} \mathrm{kg}^{-1} \mathrm{Zn}$ ), as well as for the Seine River, France (Meybeck et al. 2007), and the Bílina River, Czech Republic (Kohušová et al. 2011) (600 to $800 \mathrm{mg} \mathrm{kg}^{-1}$ $\mathrm{Zn}$ ). Due to low mobility of $\mathrm{Zn}$ (concentrations in the easily soluble fraction was in general below $5 \%$ ), the potential environmental hazard and threat for the aquatic organisms from $\mathrm{Zn}$ was appraised to be low.

The highest concentrations of total $\mathrm{P}$ in the sediments of the Sava River (Fig. S2) (between 1000 and $1500 \mathrm{mg} \mathrm{kg}^{-1}$ of total $\mathrm{P}$ ) were found mainly due to the use of P-containing fertilisers in agricultural areas (Litija) and also due to impact of untreated municipal sewage from big cities (use of P-containing detergents in household) in big cities (Zagreb, Belgrade). These concentrations are similar to those found in the sampling of the Sava sediments in 2005-2006 (Milačič et al. 2010). Concentrations of $\mathrm{Pb}, \mathrm{As}, \mathrm{Cu}, \mathrm{Sb}, \mathrm{V}, \mathrm{Mo}, \mathrm{Co}, \mathrm{Se}, \mathrm{Ba}, \mathrm{Mn}$, $\mathrm{Ti}$ and $\mathrm{Fe}$ in sediments were in general low (see data from Fig. S2, Electronic Supplementary Material).

\section{Conclusions}

Data from the sampling campaign performed at the Sava River in September 2014 revealed that the Lagrangian approach of sampling the same water mass at the input and output boundaries of the water unit, to relate transformations of dissolved and suspended contaminant compounds with the travel time, was not applicable to big rivers, such as Sava. It was demonstrated that acidification of samples did not dissolve elements associated with SPM, so microwave-assisted digestion should be applied to decompose trace elements bearing minerals in whole water samples. Soluble element concentrations $(<0.45 \mu \mathrm{m})$ were significantly lower than concentrations in the whole water samples and were also below the maximal allowable values regulated by the WFD and its daughter directives. Among elements, $\mathrm{Cr}$ and $\mathrm{Ni}$ were found in moderate concentrations (around 320 and $220 \mathrm{mg} \mathrm{kg}^{-1}$, respectively) in sediments at industrially exposed sites. However, $\mathrm{Cr}$ and $\mathrm{Ni}$ exist in sparingly soluble forms and as such do not represent an environmental burden. Elevated P concentrations from 1200 to $1500 \mathrm{mg} \mathrm{kg}^{-1}$ were found at agricultural areas and big cities. In slightly elevated concentrations, $\mathrm{Cd}$ and $\mathrm{Zn}$ were also present in sediments at sites impacted by the former mining activities and untreated sewage system from the big cities. However, their portion in the easily soluble fractions was low, so $\mathrm{Cd}$ and $\mathrm{Zn}$ did not represent an environmental threat. Concentrations of $\mathrm{Pb}, \mathrm{As}, \mathrm{Cu}, \mathrm{Sb}, \mathrm{V}, \mathrm{Mo}, \mathrm{Co}$, Se and $\mathrm{Ba}$ in water, SPM and sediments of the Sava River were low. Regarding environmental status, pollution of the Sava River with elements is comparable to other moderately polluted rivers in Europe.

Acknowledgments This work has been supported by the European Communities 7th Framework Programme Funding under grant agreement no. 603629-ENV-2013-6.2.1-Globaqua and by the Ministry of Higher Education, Science, and Technology of the Republic of Slovenia (programme group P1-0143).

Open Access This article is distributed under the terms of the Creative Commons Attribution 4.0 International License (http:// creativecommons.org/licenses/by/4.0/), which permits unrestricted use, distribution, and reproduction in any medium, provided you give appropriate credit to the original author(s) and the source, provide a link to the Creative Commons license, and indicate if changes were made. 


\section{References}

Alvarez-Guerra M, Viguri JR, Casado-Martínez MC, DelValls TÁ (2007) Sediment quality assessment and dredged material management in Spain: part I, application of sediment quality guidelines in the Bay of Santander. Integr Environ Assess Manag 3:529-538

Bakke T, Källqvist T, Ruus A, Breedveld GD, Hylland K (2010) Development of sediment quality criteria in Norway. J Soils Sediments 10:172-178

Bird G, Brewer PA, Macklin MG, Nikolova M, Kotsev T, Mollov M, Swain C (2010) Dispersal of contaminant metals in the miningaffected Danube and Maritsa drainage basins, Bulgaria, Eastern Europe. Water Air Soil Pollut 206:105-127

Bouche J, Gaillardet J, France-Lanord C, Maurice L, Dutra-Maia P (2011) Grain size control of river suspended sediment geochemistry: clues from Amazon River depth profiles. Geochem Geophys Geosyst 12:1-24

CCME - Canadian Council of Ministers of the Environment (2001) Canadian sediment quality guidelines for the protection of aquatic life

Dundar MS, Altundag H, Eyupoglu V, Keskin SC, Tutunoglu C (2012) Determination of heavy metals in lower Sakarya river sediments using BCR-sequential extraction procedure. Environ Monit Assess 184:33-41

European Communities Environmental Objectives (2009) (Surface waters) regulations S.I. no. 272/2009

European Communities Technical Report 2010-041 (2010) Common implementation strategy for the water framework directive (2000/60/ EC), guidance document No. 25 on chemical monitoring of sediment and biota under the water framework directive

Comero S, Vaccaro S, Locoro G, De Capitani L, Gawlik BM (2014) Characterization of the Danube River sediments using the PMF multivariate approach. Chemosphere 95:329-335

Dragun Z, Roje V, Mikac N, Raspor B (2009) Preliminary assessment of total dissolved trace metal concentrations in Sava River water. Environ Monit Assess 159:99-110

Dragun Z, Kapetanović D, Raspor B, Teskeredžić E (2011) Water quality of medium size watercourse under baseflow conditions: the case study of river Sutla in Croatia. Ambio 40:391-407

Grosbois C, Meybeck M, Horowitz A, Ficht A (2006) The spatial and temporal trends of $\mathrm{Cd}, \mathrm{Cu}, \mathrm{Hg}, \mathrm{Pb}$ and $\mathrm{Zn}$ in Seine River floodplain deposits (1994-2000). Sci Total Environ 356:22-37

Gottler RA (2012) Part 3000 metals. In: Rice EW, Braid RB, Eaton AD, Clesce LS (eds) Standard methods for the examination of water and waste water, 22nd edn. Port City press, Baltimore, pp. 3-1-3-11

Giusti I, Taylor A (2007) Natural and antrophogenic contamination of the Fratta-Gorzone River (Veneto, Italy). Environ Monit Assess 134: 211-231

House WA, Denison FH (2002) Total phosphorus content of river sediments in relationship to calcium, iron and organic matter concentrations. Sci Total Environ 282-283:341-351

Howell J-A (2010) The distribution of phosphorus in sediment and water downstream from a sewage treatment works. Biosci Horiz 3:113-123

ICPDR (International Commission for the Protection of the Danube River) Joint Danube Survey 2 (2008) Final Scientific report of the International Commission for the protection of the Danube River. Vienna, Austria. https://www.icpdr.org/jds/files/ICPDR Technical Report_for_web_low_corrected.pdf. Last Accessed June 2016

International Sava River Basin Commission (2002) Protocol on sediment management to the framework agreement on the Sava River Basin $\mathrm{http}: / /$ www.savacommission.org/dms/docs/dokumenti/documents publications/basic_documents/protocols/protokol_nanos.pdf. Last Accessed June 2016

International Sava River Basin Commission (2013) Sava River Basin management plan, background paper no.2: groundwater bodies in the Sava River Basin-Annex $1 \mathrm{http} / /$ www.savacommission. org/dms/docs/dokumenti/srbmp_micro_web/backgroundpapers_ final/nnno_2 background paper_gwbs_in the sava_rb.pdf. Last Accessed June 2016

ISO 15586 (2003) Water quality - determination of trace elements using atomic absorption spectrometry with graphite furnace

ISO 5667-3 (2012) Water quality - sampling - part 3: preservation and handling of water samples

Karadede-Akin H, Ünlü E (2007) Heavy metal concentrations in water, sediment, fish and some benthic organisms from Tigris River, Turkey. Environ Monit Assess 131:323-337

Kohušová K, Havle L, Vlasák P, Tonika J (2011) A long-term survey of heavy metals and specific organic compounds in biofilms, sediments, and surface water in a heavily affected river in the Czech Republic. Environ Monit Assess 174:555-572

Kotnik J, Horvat M, Milačič R, Ščančar J, Fajon V, Kryžanovski A (2003) Heavy metals in the sediments of the Sava River, Slovenia. Geologija 46:263-272

Kwok KWH, Batley GE, Wenning RJ, Zhu L, Vangheluwe M, Lee S (2014) Sediment quality guidelines: challenges and opportunities for improving sediment management. Environ Sci Pollut Res Int 21:17-27

Long ER, Ingersoll CG, MacDonald DD (2006) Calculation and uses of mean sediment quality guideline quotients: a critical review. Environ Sci Technol 40:1726-1736

Loring DH, Rantala RRT (1992) Manual for the geochemical analysis of marine sediments and suspended particulate matter. Earth Sci Rev $32: 325-238$

MacDonald DD, Ingersoll CG, Berger TA (2000) Development and evaluation of consensus-based sediment quality guidelines for freshwater ecosystems. Arch Environ Contam Toxicol 39:20-31

McCready S, Birch GF, Long ER, Spyrakis G, Greely CR (2006) An evaluation of Australian sediment quality guidelines. Arch Environ Contam Toxicol 50:306-315

Meybeck M, Lestel L, Bonté P, Moilleron R, Colin J-L, Rousselot O, Hervé D, de Pontèves C, Grosbois C, Thevénot DR (2007) Historical perspective of heavy metals contamination $(\mathrm{Cd}, \mathrm{Cr}, \mathrm{Cu}$, $\mathrm{Hg}, \mathrm{Pb}, \mathrm{Zn}$ ) in the Seine River basin (France) following a DPISIR approach (1950-2005). Sci Total Environ 375:204-231

Merrington G, Sprang P (2014) Deriving environmental quality standards in European surface waters: when are there too few data? Environ Sci Pollut Res 21:67-76

Milačič R, Ščančar J, Murko S, Kocman D, Horvat M (2010) A complex investigation of the extent of pollution in sediments of the Sava River. Part 1. Selected elements. Environ Monit Assess 163:263-275

Mohiuddin KM, Otomo K, Ogawa Y, Shikazano N (2012) Seasonal and spatial distribution of trace elements in the water and sediments of the Tsurumi River in Japan. Environ Monit Assess 184:265-279

Navarro-Ortega A, Acuña V, Bellin A, Burek P, Cassiani G, ChoukrAllah R, Dolédec S, Elosegi A, Ferrari F, Ginebreda A, Grathwohl P, Jones C, Ker Rault P, Kok K, Koundouri P, Ludwig RP, Milacic R, Muñoz I, Paniconi C, Paunović M, Petrovic M, Sabater S, Skoulikidis NT, Slob A, Teutsch G, Voulvoulis N, Barceló D (2015) Managing the effects of multiple stressors on aquatic ecosystems under water scarcity. Sci Total Environ 503/504:3-9

Novotnik B, Zuliani T, Ščančar J, Milačič R (2015) Content of trace elements and chromium speciation in neem powder and tea infusions. J Trace Elem Med Biol 31:98-106

Official Journal of the European Communities (2000) Directive 2000/60/ EC of the European parliament and of the council establishing a framework for community action in the field of water policy L 327/1

Official Journal of the European Union (2009) Commission Directive 2009/90/EC laying down, pursuant to Directive 2000/60/EC of the European Parliament and of the Council, technical specifications for chemical analysis and monitoring of water status. L 201:36-38

Quevauviller P, Rauret G, López-Sánchez JF, Rubio R, Ure A, Muntau H (1997) Certification of trace metal extractable contents in a sediment 
reference material (CRM 601) following a three-step sequential extraction procedure. Sci Total Environ 205:223-234

Sakan SM, Đorđević DS, Manojlović DD (2010) Trace elements at traces of environmental pollution in the canal sediments (alluvial formation of the Danube River, Serbia). Environ Monit Assess 167:219-233

Svete P, Milačič R, Pihlar B (2001) Partitioning of $\mathrm{Zn}, \mathrm{Pb}$, and Cd in river sediments from lead and zinc mining area using the BCR three-step extraction procedure. J Environ Monit 3:586-590

Šajn R, Gosar M (2007) Soil pollution in surroundings of Litija as a reflection of mining, metallurgy and natural conditions. Geologija 50:131-145

Š̈̈men Joksič A, Katz SA, Horvat M, Milačič R (2005) Comparison of single and sequential extraction procedures for assessing metal leaching from dredged costal sediments. Water Air Soil Pollut 162: 265-283

Tessier A, Campbell PGC, Bisson M (1979) Sequential extraction procedure for the speciation of particulated metals. Anal Chem 51:844 851
Vasile GD, Nicolau M, Vlădescu L (2010) Zinc speciation in sediments from a polluted river, as an estimate of its bioaccesibility. Environ Monit Assess 160:71-81

Vignati D, Pardos M, Diserens J, Ugazio G, Thomas R, Dominik J (2003) Characterisation of bed sediments and suspension of the river Po (Italy) during normal and high flow conditions. Water Res 37:2847-2864

Vignati DAL, Secrieru D, Bogatova YI, Dominik J, Céréghino R, Berlinsky NA, Oaie G, Szobotka S, Stanica A (2013) Trace element contamination in the arms of the Danube Delta (Romania/Ukraine): current state of knowledge and future needs. J Environ Manag 125:169-178

Writer JH, Keefe SK, Ryan JN, Ferrer I, Thurman ME, Barber LB (2011) Methods for evaluating in-stream attenuation of trace organic compounds. Appl Geochem 26:S344-S345

Zuliani T, Mladenovič A, Ščančar J, Milačič R (2016) Chemical characterisation of dredged sediments in relation to their potential use in civil engineering. Environ Monit Assess 188:234 